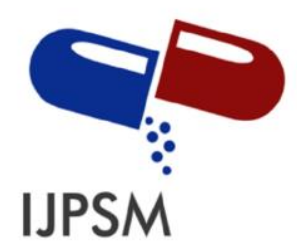

Sesni Yuli Zarmi et al, Int. Journal of Pharmaceutical Sciences and Medicine (IJPSM),

Vol.6 Issue. 3, March- 2021, pg. 1-13

ISSN: 2519-9889

Impact Factor: 3.426

\title{
Review of Phytochemicals and Pharmacology of Medicinal Plants to Lower Blood Fat Levels
}

\author{
Sesni Yuli Zarmi ${ }^{1}$; Rina Desni Yetti ${ }^{1}$ Harrizul Rivai $^{2^{*}}$ \\ ${ }^{1}$ College of Pharmacy (STIFARM), Jl. Raya Siteba Kurao Pagang, Padang 25147, Indonesia \\ ${ }^{2}$ Faculty of Pharmacy, Andalas University, Limau Manih Campus, Padang 25163, Indonesia \\ "Email: harrizul@yahoo.co.id and harrizul@ phar.unand.ac.id \\ DOI: 10.47760/ijpsm.2021.v06i03.001
}

\begin{abstract}
This review aims to seek information about the phytochemical and pharmacological activities of plants used traditionally to reduce blood lipid levels. The way to find information is to conduct literature studies to find sources or literature in primary data or official books and national and international journals in the last ten years (2010-2020). In doing this review, the search for data using online media with keywords is Phytochemical, Pharmacology, Lowering Blood Fat Levels. Search for the primary references used in this review article's production through trusted websites, namely Google Scholar, Science Direct, NCBI, ResearchGate, and other published and reliable journals. The results show that six herbs are used traditionally to lower blood lipid levels. The six plants contain carbohydrates, tannins, alkaloids, steroids, triterpenoids, flavonoids, glycosides, phenolics, saponins, polyphenols, quercetin, terpenoids, sterol glycosides, flavonols, and formic acid. These six herbs have been shown to work as anti-hypercholesterolemic agents. Thus, it can be concluded that six plants in Indonesia can be developed into phytopharmaca as anti-hypercholesterolemic drugs.
\end{abstract}

Keywords: Antihypercholesterolemia, medicinal plants, phytochemicals, pharmacology, lowering blood lipid levels.

\section{Introduction}

According to the Food and Drug Administration of the Republic of Indonesia (2011) [1], blood fats consist of triglycerides and cholesterol. Cholesterol is a fat-like substance (lipid) found in cell membranes and is a precursor to bile acids and steroid hormones. Cholesterol in the blood circulation is bound to lipoproteins. There are two kinds of lipoproteins: high-density lipoprotein (HDL), good cholesterol, and Low-Density Lipoprotein (LDL), known as bad cholesterol. LDL carries cholesterol from the liver to the body's parts where it is needed, while HDL carries excess cholesterol in the blood to the liver for reprocessing.

Also, there is something called triglycerides, which are excess calories stored in fat cells in the blood. The body needs normal levels of triglycerides. Total cholesterol contains 60-70\% LDL, 20-30\% HDL and 10-15\% 


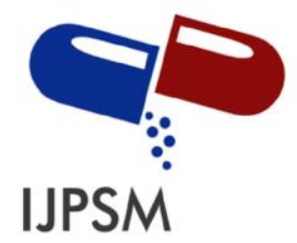

Sesni Yuli Zarmi et al, Int. Journal of Pharmaceutical Sciences and Medicine (IJPSM), Vol.6 Issue. 3, March- 2021, pg. 1-13

ISSN: 2519-9889

Impact Factor: 3.426

triglycerides. Under normal circumstances, cholesterol is needed by the body for the growth of brain and nerve tissue, the formation of body cells, and a precursor for the formation of bile acids and steroid hormones. However, if the amount of LDL and triglycerides is excessive, the lipoproteins will stick to the coronary blood vessels' walls and can cause plaque known as atherosclerotic plaque. Hypercholesterolemia or also known as high cholesterol, is the presence of high cholesterol levels in the blood. It is a form of hyperlipidemia, high blood lipids, and hyperlipoproteinemia (increased lipoproteins levels in the blood) [2].

Many people use plants as a traditional medicine to reduce blood lipid levels because chemical drugs have many side effects from medications. Therefore, it is necessary to look for medicinal plants that can reduce blood lipid levels. The POM RI has determined that the plants Salam (Syzygium polyanthum), Alang-Alang (Imperata cylindrica L), Pegagan (Centella asiatica L), Sambiloto (Andrographis paniculata), Sweet Potatoes (Ipomoea batatas), and Sambung Nyawa (Gynura procumbens) can be used as an herb to lower blood fat levels [1]. Therefore, it is necessary to collect phytochemical and pharmacological information from these plants.

\section{Method of data collection}

In compiling this review article, the technique used is to use literature studies by finding sources or literature in primary data or the shape of official books and international journals in the last ten years (2010-2020). The search for data used online media with keywords such as phytochemistry, pharmacology, and lowering blood fat levels in doing this review. Search for the primary references used in this review article's production through trusted websites, namely Google Scholar, Science Direct, NCBI, ResearchGate, and other published and reliable journals.

\section{Medicinal plants used to lower blood lipid levels}

According to the POM RI [1], six medicinal plants can lower blood lipid levels. The six plants are Salam (Syzygium polyanthum), Alang-Alang (Imperata cylindrica L), Pegagan (Centella asiatica L), Sambiloto (Andrographis paniculata), Sweet Potatoes (Ipomoea batatas), and Sambung Nyawa (Gynura procumbens). Each plant will be described both phytochemical and pharmacological activities, especially in reducing blood lipid levels.

3.1 Salam or Bay (Syzygium polyanthum)

Bay leaves and flowers that can be used to lower blood lipid levels are shown in Figure 1 below.

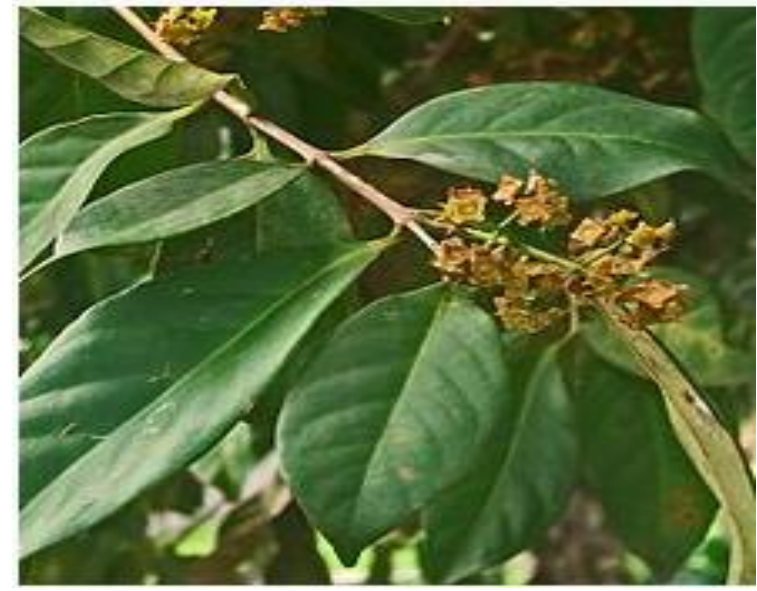

Figure 1: Leaves and flowers of Salam (Syzygium polyanthum) [3]

This study aims to extract the phytochemical compounds in S. polyanthum leaves using ultrasound-assisted extraction (UAE) and identify them with Gas Chromatography-Mass Spectrometry (GC-MS) analysis. The leaves were consecutively soaked with n-hexane, ethyl acetate, and methanol in a sonicator bath to obtain 


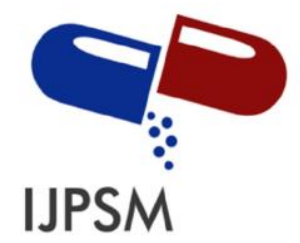

Sesni Yuli Zarmi et al, Int. Journal of Pharmaceutical Sciences and Medicine (IJPSM), Vol.6 Issue. 3, March- 2021, pg. 1-13

ISSN: 2519-9889

Impact Factor: 3.426

extracts of n-hexane (HSP), ethyl acetate (EASP), and methanol (MSP) of $S$. polyanthum leaves (Table 1), then the extract was carried out. GC-MS analysis. Compared with the Wiley, NIST, and FNSCC libraries for compound identification, the peak mass spectral databases were compared. GC-MS analysis of HSP, EASP, and MSP revealed the presence of heights of 21 peaks, respectively (Figure 2, Table 2), 27 peaks (Figure 3, Table 3), and 31 peaks (Figure 4, Table 4). The main compounds for HSP $(31,912 \%)$, EASP $(27,042 \%)$, and MSP $(22,386 \%)$ are unknown compounds detected at retention times between 61,980 and 62.29 minutes so they require further characterization. Squalene and phytol were among the other main compounds present in all three extracts. Several compounds identified in extracts such as squalene, phytol, hentriacontane, palmitic acid, $\alpha$-pinene, nerolidol, linalool, $\alpha$-tocopherol, and $\beta$-tocopherol are known to be bioactive compounds. Thus GCMS analysis of n-hexane (HSP), ethyl acetate (EASP), and methanol (MSP) from S. polyanthum leaf extract has revealed the presence of several known bioactive compounds of therapeutic importance [5].

Table 1: Percentage yield of n-hexane, ethyl acetate, and methanol extracts from S. polyanthum leaves [5]

\begin{tabular}{|c|c|c|c|c|c|c|c|c|c|}
\hline \multirow{3}{*}{ Batch No. } & \multirow{3}{*}{$\begin{array}{l}\text { Fresh } \\
\text { weight } \\
(\mathbf{k g})\end{array}$} & \multicolumn{2}{|c|}{ Yields After Drying } & \multicolumn{6}{|c|}{ Final Yield } \\
\hline & & \multirow{2}{*}{$\begin{array}{l}\text { Dry Weight } \\
(\mathbf{k g})\end{array}$} & \multirow{2}{*}{$\begin{array}{c}\% \\
\text { (Wet basis) }\end{array}$} & \multicolumn{2}{|c|}{ HSP } & \multicolumn{2}{|c|}{ EASP } & \multicolumn{2}{|c|}{ MSP } \\
\hline & & & & $\begin{array}{l}\text { Weight } \\
\text { (g) }\end{array}$ & $\begin{array}{c}\% \\
\text { (Dry basis) }\end{array}$ & $\begin{array}{l}\text { Weight } \\
\text { (g) }\end{array}$ & $\begin{array}{c}\% \\
\text { (Dry basis) }\end{array}$ & $\begin{array}{l}\text { Weight } \\
\text { (g) }\end{array}$ & $\begin{array}{c}\% \\
\text { (Dry basis) }\end{array}$ \\
\hline 1 & 0.7 & 0.30 & 42.86 & 3.39 & 1.13 & 6.65 & 2.22 & 16.49 & 5.50 \\
\hline 2 & 0.6 & 0.30 & 50.00 & 6.89 & 2.30 & 15.03 & 5.01 & 21.81 & 7.27 \\
\hline & & Total & & & $1.72 \pm 0.83$ & & $3.62 \pm 1.97$ & & $6.39 \pm 1.25$ \\
\hline
\end{tabular}

Note: Final results are expressed as percentage mean \pm standard deviation. HSP: S. polyanthum leaf n-Hexane extract, EASP: S. polyanthum leaf ethyl acetate extract, and MSP: S. polyanthum leaf methanol extract.

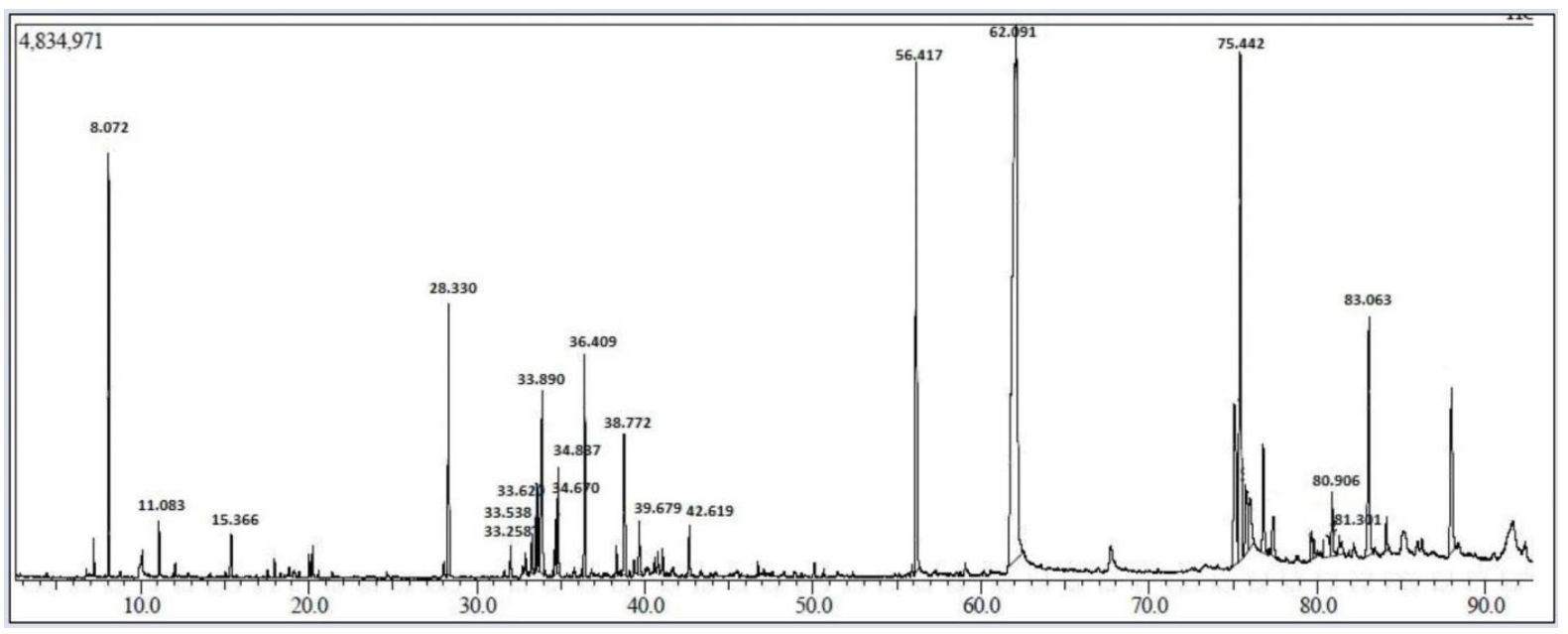

Figure 2: GC-MS chromatogram of S. polyanthum leaf n-hexane extract. 


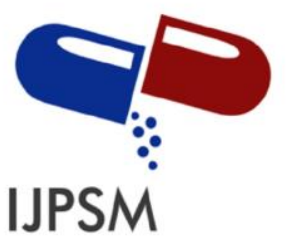

Sesni Yuli Zarmi et al, Int. Journal of Pharmaceutical Sciences and Medicine (IJPSM), Vol.6 Issue. 3, March- 2021, pg. 1-13

ISSN: 2519-9889

Impact Factor: 3.426

Table 2: Phytochemical compounds in the n-hexane extract of $S$. polyanthum leaves [5]

\begin{tabular}{|c|c|c|c|c|}
\hline Name & $\begin{array}{l}\text { Peak } \\
\%\end{array}$ & Chemical Classes & Molecular Formula & $\begin{array}{l}\text { Retention Time } \\
(\min )\end{array}$ \\
\hline a-Pipene & 4.921 & Monoterpene & $\mathrm{C}_{10} \mathrm{H}_{16}$ & 8.072 \\
\hline Octanal & 0.573 & Aldehyde & $\mathrm{C}_{8} \mathrm{H}_{16} \mathrm{O}$ & 11.083 \\
\hline Linalool & 0.448 & Oxygenated monoterpene & $\mathrm{C}_{10} \mathrm{H}_{18} \mathrm{O}$ & 15.366 \\
\hline a-Cubebene & 3.633 & Sesquiterpene & $\mathrm{C}_{15} \mathrm{H}_{24}$ & 28.330 \\
\hline 2-Isopropenyl-4a,8-dimethyl-1,2,3,4,4a,5,6,7-octahydronaphthalene & 0.558 & - & $\mathrm{C}_{15} \mathrm{H}_{24}$ & 33.258 \\
\hline Azulene & 1.255 & Sesquiterpene derivatives & $\mathrm{C}_{15} \mathrm{H}_{24}$ & 33.538 \\
\hline Valencene & 1.097 & Sesquiterpene & $\mathrm{C}_{15} \mathrm{H}_{24}$ & 33.620 \\
\hline$\beta$-Panasinsene & 3.990 & Volatile compounds & $\mathrm{C}_{15} \mathrm{H}_{24}$ & 33.892 \\
\hline$\delta$-Cadinene & 0.737 & Bicyclic sesquiterpene & $\mathrm{C}_{15} \mathrm{H}_{24}$ & 34.670 \\
\hline$\alpha$-Panasinsen & 1.515 & Sesquiterpene, & $\mathrm{C}_{15} \mathrm{H}_{24}$ & 34.848 \\
\hline Nerolidol & 2.845 & Sesquiterpene & $\mathrm{C}_{15} \mathrm{H}_{26} \mathrm{O}$ & 36.417 \\
\hline Humulene epoxide II & 2.060 & Peroxide & $\mathrm{C}_{15} \mathrm{H}_{24} \mathrm{O}$ & 38.772 \\
\hline Caryophyllene oxide & 0.846 & $\begin{array}{l}\text { Oxygenated terpenoid/ } \\
\text { sesquiterpene }\end{array}$ & $\mathrm{C}_{15} \mathrm{H}_{24} \mathrm{O}$ & 39.679 \\
\hline Farnesol & 0.715 & Acyclic alcoholic sisquiterpene & $\mathrm{C}_{15} \mathrm{H}_{26} \mathrm{O}$ & 42.619 \\
\hline Phytol & 8.409 & Diterpene alcohol & $\mathrm{C}_{20} \mathrm{H}_{40} \mathrm{O}$ & 56.147 \\
\hline RT:62.093 & 31.912 & - & - & 62.091 \\
\hline Squalene & 8.776 & Triterpene & $\mathrm{C}_{30} \mathrm{H}_{50}$ & 75.442 \\
\hline$\beta$-Tocopherol & 0.934 & Tocopherol (methylated phenols) & $\mathrm{C}_{28} \mathrm{H}_{48} \mathrm{O}_{2}$ & 80.906 \\
\hline$\gamma$-Tocopherol & 0.934 & Tocopherol (methylated phenols) & $\mathrm{C}_{28} \mathrm{H}_{48} \mathrm{O}_{2}$ & 81.301 \\
\hline a-Tocopherol & 0.340 & Tocopherol (methylated phenols) & $\mathrm{C}_{29} \mathrm{H}_{50} \mathrm{O}_{2}$ & 83.063 \\
\hline$\beta$-Sitosterol & 0.676 & Steroidal & $\mathrm{C}_{29} \mathrm{H}_{50} \mathrm{O}$ & 87.992 \\
\hline \multicolumn{5}{|c|}{ Total $=77.174 \%$} \\
\hline
\end{tabular}

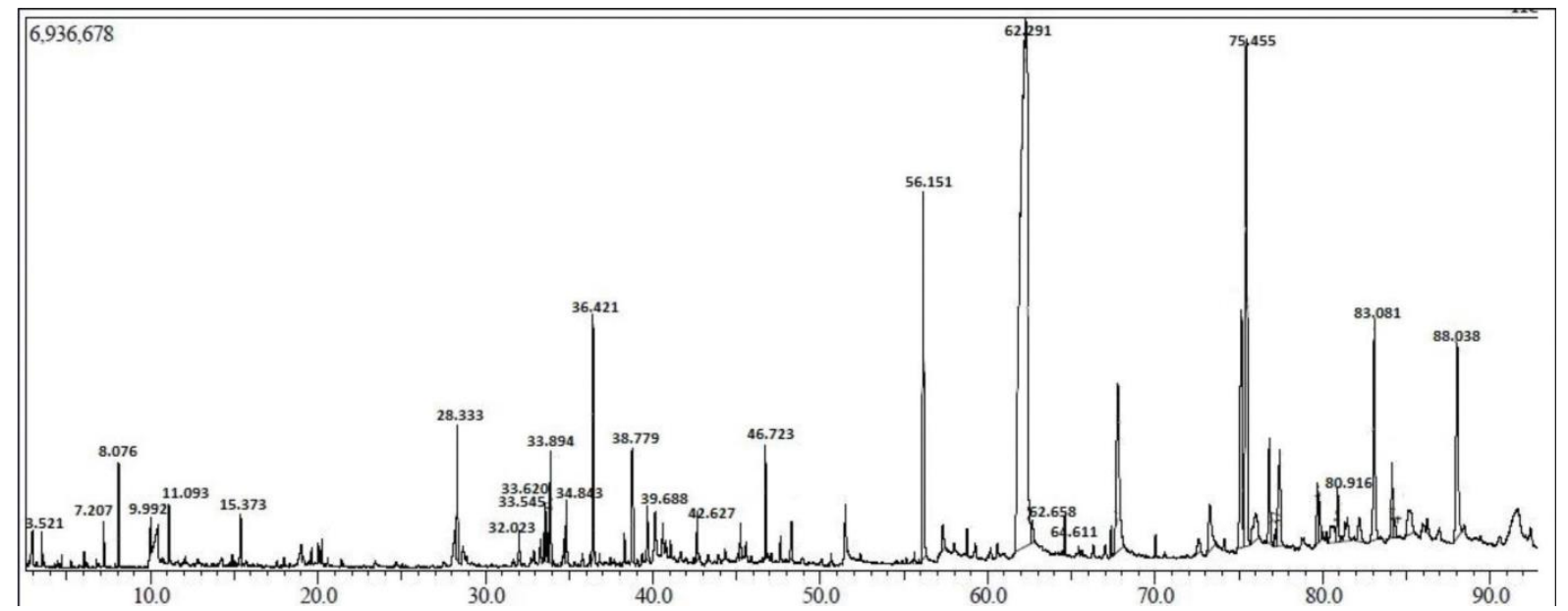

Figure 3: GC-MS chromatogram of ethyl acetate extract of S. polyanthum leaves. 


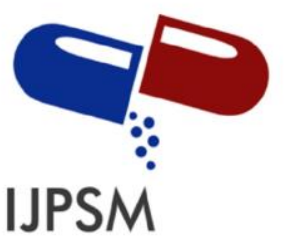

Sesni Yuli Zarmi et al, Int. Journal of Pharmaceutical Sciences and Medicine (IJPSM), Vol.6 Issue. 3, March- 2021, pg. 1-13

ISSN: 2519-9889

Impact Factor: 3.426

Table 3: Phytochemical compounds in ethyl acetate extract of $S$. polyanthum leaves [5]

\begin{tabular}{|c|c|c|c|c|}
\hline Name & Peak \% & Chemical Classes & Molecular Formula & Retention Time (min) \\
\hline Propylene glycol & 0.144 & Diol & $\mathrm{C}_{3} \mathrm{H}_{8} \mathrm{O}_{2}$ & 3.521 \\
\hline n-Heptanal & 0.317 & Aldehyde & $\mathrm{C}_{7} \mathrm{H}_{14} \mathrm{O}$ & 7.207 \\
\hline a-Pinene & 1.068 & Monoterpene & $\mathrm{C}_{10} \mathrm{H}_{16}$ & 8.076 \\
\hline Heptane & 0.389 & Alkane & $\mathrm{C}_{7} \mathrm{H}_{16}$ & 9.992 \\
\hline Octanal & 0.563 & Aldehyde & $\mathrm{C}_{8} \mathrm{H}_{16} \mathrm{O}$ & 11.093 \\
\hline$\beta$-linalool & 0.468 & Terpene alcohol & $\mathrm{C}_{10} \mathrm{H}_{18} \mathrm{O}$ & 15.373 \\
\hline a-Cubebene & 1.690 & Sesquiterpene & $\mathrm{C}_{15} \mathrm{H}_{24}$ & 28.333 \\
\hline$\alpha$-Humulene & 0.504 & Monocyclic sesquiterpene & $\mathrm{C}_{15} \mathrm{H}_{24}$ & 32.023 \\
\hline$\beta$-Selinene & 0.735 & Sesquiterpene & $\mathrm{C}_{15} \mathrm{H}_{24}$ & 33.545 \\
\hline Valencene & 0.548 & Sesquirterpene & $\mathrm{C}_{15} \mathrm{H}_{24}$ & 33.620 \\
\hline 1H-Cyclopropa[a]naphthalene & 2.226 & Acyclic alkene & $\mathrm{C}_{15} \mathrm{H}_{24}$ & 33.894 \\
\hline$\alpha$-Panasinsen & 0.887 & Sesquirterpene & $\mathrm{C}_{15} \mathrm{H}_{24}$ & 34.843 \\
\hline Nerolidol & 3.085 & Sesquiterpene alcohol & $\mathrm{C}_{15} \mathrm{H}_{26} \mathrm{O}$ & 36.423 \\
\hline Humulene epoxide II & 1.557 & Sesquiterpene & $\mathrm{C}_{15} \mathrm{H}_{24} \mathrm{O}$ & 38.782 \\
\hline Caryophyllene oxide & 0.824 & Oxygenated terpenoid & $\mathrm{C}_{15} \mathrm{H}_{24} \mathrm{O}$ & 39.688 \\
\hline Farnesol & 0.645 & Acyclic alcoholic sisquiterpene & $\mathrm{C}_{15} \mathrm{H}_{26} \mathrm{O}$ & 42.628 \\
\hline Neophytadiene & 1.347 & Terpenoid & $\mathrm{C}_{20} \mathrm{H}_{38}$ & 46.723 \\
\hline Phytol & 5.715 & Diterpene alcohol & $\mathrm{C}_{20} \mathrm{H}_{40} \mathrm{O}$ & 56.151 \\
\hline $9,12,15$-Octadecatrien-1-ol & 1.037 & Unsaturated alcoholic compound (Lignan) & $\mathrm{C}_{18} \mathrm{H}_{32} \mathrm{O}$ & 57.341 \\
\hline Hentriacontane & 0.303 & Long chain alkane & $\mathrm{C}_{31} \mathrm{H}_{64}$ & 58.758 \\
\hline RT:62.290 & 27.042 & - & - & 62.291 \\
\hline 2-Cyclohexen-3-ol-1-one, 2-[1-iminoethyl]- & 0.107 & - & - & 62.658 \\
\hline n-Pentacosane & 0.472 & Aliphatic hydrocarbon alkane & $\mathrm{C}_{25} \mathrm{H}_{52}$ & 64.611 \\
\hline Squalene & 8.345 & Teriterpene hydrocarbon & $\mathrm{C}_{30} \mathrm{H}_{62}$ & 75.455 \\
\hline$\beta$-Tocopherol & 0.693 & Tocopherol (methylated phenols) & $\mathrm{C}_{28} \mathrm{H}_{48} \mathrm{O}_{2}$ & 80.916 \\
\hline a-Tocopherol & 4.660 & Tocopherol (methylated phenols) & $\mathrm{C}_{29} \mathrm{H}_{50} \mathrm{O}_{2}$ & 83.081 \\
\hline$\beta$-Sitosterol & 4.959 & Steroidal & $\mathrm{C}_{29} \mathrm{H}_{50} \mathrm{O}$ & 88.038 \\
\hline \multicolumn{5}{|c|}{ Total $=70.330 \%$} \\
\hline
\end{tabular}

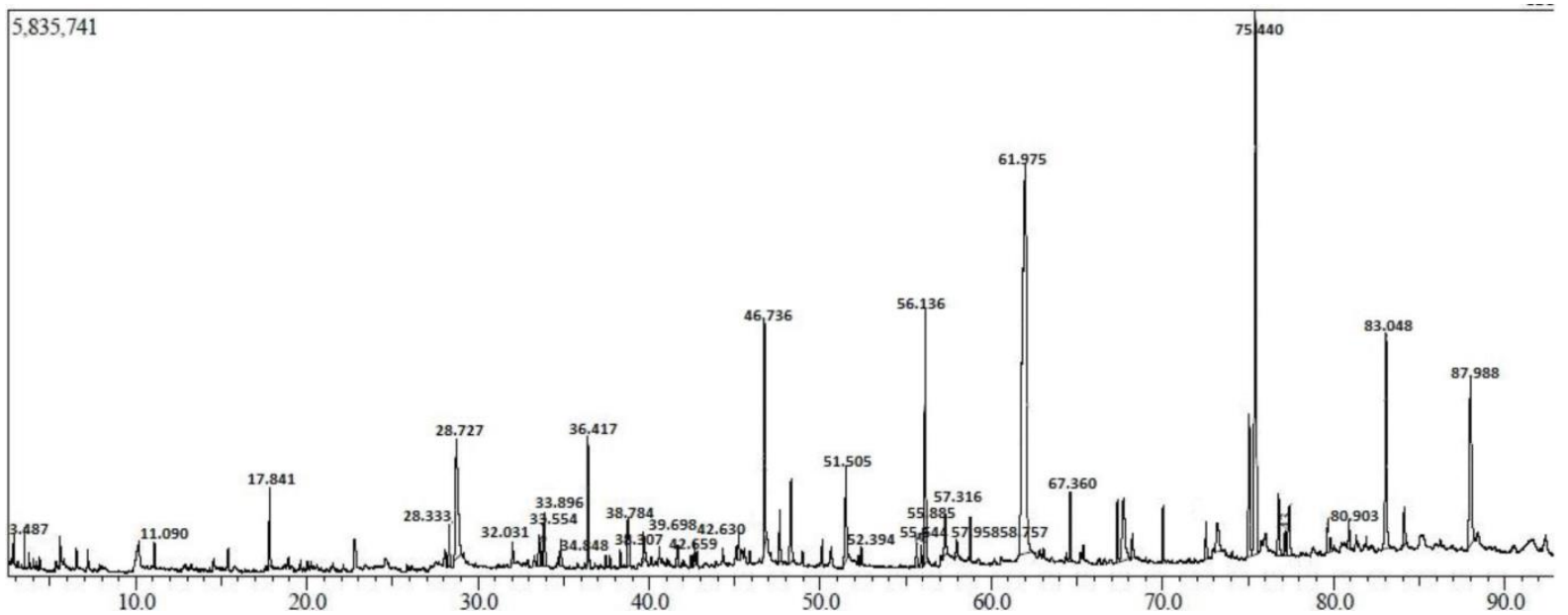

Figure 4: GC-MS chromatogram of S. polyanthum leaf methanol extract. 


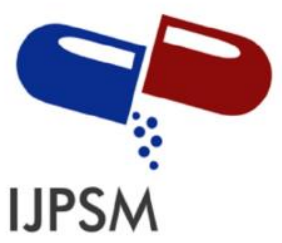

Sesni Yuli Zarmi et al, Int. Journal of Pharmaceutical Sciences and Medicine (IJPSM), Vol.6 Issue. 3, March- 2021, pg. 1-13

ISSN: 2519-9889

Impact Factor: 3.426

Table 4: Phytochemical compounds in the methanol extract of S. polyanthum leaves.

\begin{tabular}{|c|c|c|c|c|}
\hline Name & Peak \% & Chemical Classes & $\begin{array}{l}\text { Molecular } \\
\text { Formula }\end{array}$ & $\begin{array}{l}\text { Retention Time } \\
\text { (min) }\end{array}$ \\
\hline Propylene glycol & 0.272 & Diol & $\mathrm{C}_{3} \mathrm{H}_{8} \mathrm{O}_{2}$ & 3.487 \\
\hline Octanal & 0.354 & Aldehyde & $\mathrm{C}_{8} \mathrm{H}_{16} \mathrm{O}$ & 11.090 \\
\hline 2,3-Dihydro-3,5-dihydroxy-6-methyl-4H-pyran-4-one & 1.423 & Flavanoid fraction & $\mathrm{C}_{6} \mathrm{H}_{8} \mathrm{O}_{4}$ & 17.841 \\
\hline a-Copaene & 0.636 & Sesquiterpene & $\mathrm{C}_{15} \mathrm{H}_{24}$ & 28.333 \\
\hline Pyrogallol & 5.247 & Phenol & $\mathrm{C}_{6} \mathrm{H}_{6} \mathrm{O}_{3}$ & 28.727 \\
\hline a-Humulene & 0.576 & Sesquiterpene & $\mathrm{C}_{15} \mathrm{H}_{24}$ & 32.031 \\
\hline$\beta$-Panasinsene & 0.923 & Sesquiterpene & $\mathrm{C}_{15} \mathrm{H}_{24}$ & 33.554 \\
\hline Selina-4,11-diene & 1.519 & - & $\mathrm{C}_{15} \mathrm{H}_{24}$ & 33.896 \\
\hline$\alpha$-Panasinsen & 0.677 & Sesquiterpene, & $\mathrm{C}_{15} \mathrm{H}_{24}$ & 34.848 \\
\hline Nerolidol & 2.267 & Sesquiterpene & $\mathrm{C}_{15} \mathrm{H}_{26} \mathrm{O}$ & 36.417 \\
\hline$\beta$-Selinene & 0.321 & Sesquiterpene & $\mathrm{C}_{15} \mathrm{H}_{24}$ & 38.307 \\
\hline Humulene epoxide II & 0.910 & Epoxide & $\mathrm{C}_{15} \mathrm{H}_{24} \mathrm{O}$ & 38.784 \\
\hline Caryophyllene oxide & 0.943 & Oxygenated terpenoid & $\mathrm{C}_{15} \mathrm{H}_{24}$ & 39.698 \\
\hline Pentadecane, 2,6,10,14-tetramethyl- & 0.386 & Saturated terpenoid alkane & $\mathrm{C}_{19} \mathrm{H}_{40}$ & 41.659 \\
\hline Farnesol & 0.421 & Acyclic Sesquiterpene & $\mathrm{C}_{15} \mathrm{H}_{26} \mathrm{O}$ & 42.630 \\
\hline Neophytadiene & 0.581 & Terpenoid & $\mathrm{C}_{20} \mathrm{H}_{38}$ & 46.735 \\
\hline Methyl palmitate & 0.425 & Palmitic acid ester & $\mathrm{C}_{17} \mathrm{H}_{34} \mathrm{O}_{2}$ & 50.092 \\
\hline Palmitic acid & 2.378 & Fatty acid & $\mathrm{C}_{16} \mathrm{H}_{32} \mathrm{O}_{2}$ & 51.507 \\
\hline Eicosane & 0.294 & Aliphatics alkane & $\mathrm{C}_{20} \mathrm{H}_{42}$ & 52.398 \\
\hline Methyl oleate & 0.343 & Unsaturated fatty acid Methyl ester & $\mathrm{C}_{19} \mathrm{H}_{36} \mathrm{O}_{2}$ & 55.887 \\
\hline Phytol & 4.952 & Diterpene alcohol & $\mathrm{C}_{20} \mathrm{H}_{40} \mathrm{O}$ & 56.137 \\
\hline $9,12,15$-Octadecatrien-1-ol & 1.783 & Unsaturated alcoholic compound & $\mathrm{C}_{18} \mathrm{H}_{32} \mathrm{O}$ & 57.317 \\
\hline Stearic acid & 0.604 & $\begin{array}{c}\text { Stearic acid } \\
\text { Saturated fatty acid }\end{array}$ & $\mathrm{C}_{18} \mathrm{H}_{36} \mathrm{O}_{2}$ & 57.963 \\
\hline Hentriacontane & 0.674 & Alkane & $\mathrm{C}_{31} \mathrm{H}_{64}$ & 55.647 \\
\hline RT:61.980 & 22.386 & - & - & 61.975 \\
\hline Pentacosane & 1.282 & Aliphatic hydrocarbon & $\mathrm{C}_{31} \mathrm{H}_{64}$ & 58.758 \\
\hline Hexadecanoic acid, 2-hydroxy-1-(hydroxymethyl) & 0.525 & Fatty acid & $\mathrm{C}_{19} \mathrm{H}_{38} \mathrm{O}_{4}$ & 68.232 \\
\hline Squalene & 10.913 & Triterpene & $\mathrm{C}_{30} \mathrm{H}_{50}$ & 75.440 \\
\hline$\beta$-Tocopherol & 0.548 & Tocopherol compound (methylated phenols) & $\mathrm{C}_{28} \mathrm{H}_{48} \mathrm{O}_{2}$ & 80.903 \\
\hline a-Tocopherol & 4.933 & Tocopherol (methylated phenols) & $\mathrm{C}_{29} \mathrm{H}_{50} \mathrm{O}_{2}$ & 83.048 \\
\hline$\beta$-Sitosterol & 5.560 & Steroidal & $\mathrm{C}_{29} \mathrm{H}_{50} \mathrm{O}$ & 87.988 \\
\hline \multicolumn{5}{|c|}{ Total $=75.056 \%$} \\
\hline
\end{tabular}

Hypercholesterolemia is a condition in which serum cholesterol levels increase, especially Low-Density Lipoprotein (LDL) levels that exceed normal limits. The antihypercholesterolemic effect of ceremai leaf extract and bay leaf extract has been tested with a combination of 1 dose of $30 \mathrm{mg} / \mathrm{kg} \mathrm{BW}$ of ceremai leaf extract and $50 \mathrm{mg} / \mathrm{kg} \mathrm{BW}$ of bay leaf extract, a combination of 2 doses of $15 \mathrm{mg} / \mathrm{kg} \mathrm{BW}$ of ceremai leaf extract and $25 \mathrm{mg} / \mathrm{kg} \mathrm{BW}$ of bay leaf extract given to hypercholesterolemic male white rats (Rattus norvegicus). Male white rats were given a high cholesterol diet. Data analysis using ANOVA method and KK advanced test. Based on the results of research that has been done, it shows that the combination of ethanol extract of ceremai leaves with a dose of $15 \mathrm{mg} / \mathrm{kg}$ BW and ethanol extract of bay leaves $25 \mathrm{mg} / \mathrm{kg}$ BW can reduce total blood cholesterol levels in white male rats which is comparable to the positive control simvastatin [6].

The combination of Andrographis paniculata aqueous extract and aqueous Syzygium polyanthum (6: 1) was reported to reduce blood glucose in normal and alloxan rats. This combination also exerted a protective effect on the kidneys, liver and pancreas of tested animals against alloxan toxicity. Eighty male albino rats were divided into eight different groups: normal control, diabetes control, four groups of Andrographis paniculata 


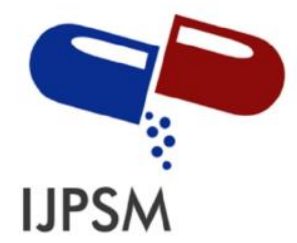

Sesni Yuli Zarmi et al, Int. Journal of Pharmaceutical Sciences and Medicine (IJPSM), Vol.6 Issue. 3, March- 2021, pg. 1-13

ISSN: 2519-9889

Impact Factor: 3.426

aqueous extract treatment groups, and Syzygium polyanthum and its combination, and standard drugs (metformin, insulin) as many as ten rats in each group. The extract and standard were given orally for seven days. On the 7th day of blood sampling, the serum was separated, and the levels of glucose, total cholesterol, LDL, HDL, triglycerides, and alkaline phosphatase were determined. Recording body weight on days 1 and 7 . The data obtained showed that the aqueous extract of Andrographis paniculata (WAP), an aqueous extract of Syzygium polyanthum (WSP) and their combinations (1 WAP: 6 WSP; 6 WAP: 1 WSP)) reduced glucose levels. The treatment with this extract also significantly reduced LDL and triglyceride levels and alkaline phosphatase levels compared to the normal and diabetic groups. Aqueous extract of Andrographis paniculata, an aqueous extract of Syzygium polyanthum, and their combination have significant antidiabetic activity as well as antihypercholesterolemic activity [7].

\subsection{Alang-Alang (Imperata cylindrica $L$ )}

The roots, leaves, and flowers of alang-alang that can be used to lower blood fat levels are shown in Figure 5 below.

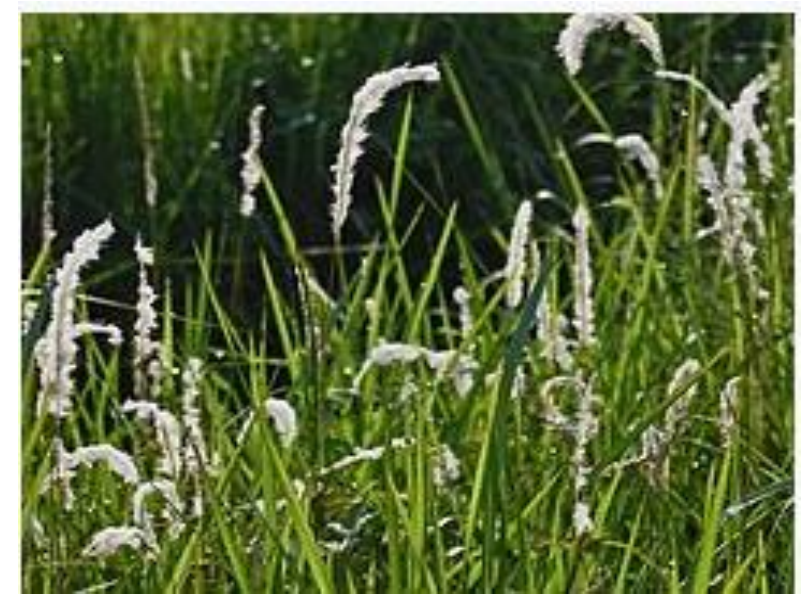

Figure 5: Leaves and flowers of Alang-Alang (Imperata cylindrica L) [8]

Alang-Alang (Imperata cylindrica / I. cylindrica) from the Gramineae family is abundant in nature. The roots of this plant have several beneficial biological activities. This study aims to isolate and identify flavonoids from Alang-Alang roots and test their potential as hypocholesterolemic agents. Flavonoid compounds were isolated by the maceration method, followed by gravity column chromatography until pure compounds were obtained. The molecular structure of isolated compounds was determined using ${ }^{1} \mathrm{H}^{-}$nuclear magnetic resonance (NMR) and ${ }^{13} \mathrm{C}^{-}$NMR spectroscopy. In vivo, lipid-lowering tests used a group experimental design control was only randomized post-test in mice with hypercholesterolemia. The animals were divided into four groups: $\mathrm{K} 0$, negative control; K1, positive control; K2, the ethanol extract treatment group; and K3, the ethyl acetate fraction treatment group, and the lipid profile was examined at the end of the study. The compound isolated, 7,3',5'-trimethoxyflavonol, was collected in the form of a yellow powder; it proved to be a flavonoid and consists of 18 carbon atoms and 16 hydrogen atoms. In vivo tests showed that the ethanol extract 15 $\mathrm{mg} / 200 \mathrm{~g}$ body weight $(\mathrm{BW})$ significantly reduced total cholesterol levels $(\mathrm{P}=0.001)$ but did not decrease low density lipoproteins (LDL) $(\mathrm{P}=0.109)$ and high density lipoproteins $(\mathrm{HDL})(\mathrm{P}=0.003)$. Ethyl acetate fraction given at $15 \mathrm{mg} / 200 \mathrm{~g} \mathrm{BW}$ was able to significantly reduce total cholesterol levels $(\mathrm{P}=0.002)$ and reduce LDL levels $(\mathrm{P}=0.006)$ but was unable to increase HDL levels $(\mathrm{P}=0.190)$. The in vivo test showed that the ethyl acetate fraction of I. cylindrica reduced total and LDL cholesterol levels more effectively than ethanol extract but did not affect HDL levels in hypercholesterolemic rats [9].

Imperata extract was studied to affect the absorption rate of cholesterol in mice (Mus muscular). Male mice (20-25 g) were divided into the control group and the previous treatment group. The treatment group was 


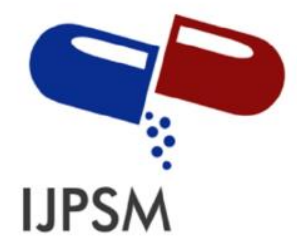

Sesni Yuli Zarmi et al, Int. Journal of Pharmaceutical Sciences and Medicine (IJPSM), Vol.6 Issue. 3, March- 2021, pg. 1-13

ISSN: 2519-9889

Impact Factor: 3.426

further divided into two groups with different doses of Imperata extract $(90 \mathrm{mg} / \mathrm{kg}$ and $115 \mathrm{mg} / \mathrm{kg} \mathrm{BW}$ ) for two weeks. The mice were fasted 12 hours before being given acute olive oil at a dose of $10 \mu \mathrm{L} / \mathrm{g}$, and blood was drawn at time points 0,2 , and 6 hours on the specified day. Blood is collected from the retroorbital plexus at a designated point in time. Total cholesterol levels were significantly $(\mathrm{p}<0.05)$ decreased in both groups treated previously at 6 hours after acute olive oil administration. It can be concluded that the significant effect of Imperata extract on reducing serum cholesterol levels indicates its potential impact as an antihypercholesterolemic therapy [10].

\subsection{Pegagan (Centella asiatica)}

Pegagan herbs that can be used to lower blood fat levels are shown in Figure 6 below.

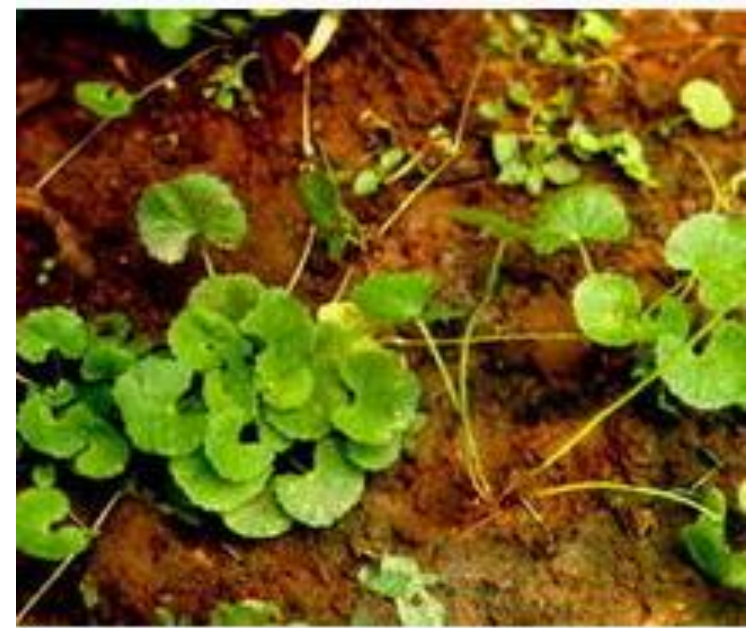

Figure 6: Herbs of Pegagan (Centella asiatica) [11]

Centella asiatica is a herbaceous plant commonly known as Gotu Kola and belongs to the Apiaceae family. This plant is found in most tropical and subtropical countries that grow in swampy areas. This plant is a tasteless, odorless plant and is traditionally used for the treatment of various diseases. The leaves and roots are used as a vegetable and for medicinal purposes. Knowledge of their contribution to human nutrition and bioactive components' content is lacking and has limited their use. Therefore, this study evaluated the nutritional content and phytochemical composition of Gotu kola leaves using standard methods. Proximate analysis of this plant shows water content of $13.10 \pm 1.07 \%$, ash $16.5 \pm 0.45 \%$, protein $8.35 \pm 1.28 \%$, fat 1.20 $\pm 0.10 \%$, fiber $17.00 \pm 1.87 \%$ and carbohydrates $43.81 \pm 0.70 \%$. The physicochemical analysis showed a saponification value of $238.43 \mathrm{mg} / \mathrm{KOH}$. The fatty acid composition showed high palmitic acid concentrations $(55.70 \%)$ as saturated acid and linoleic acid (17.50\%) as unsaturated fatty acids. Meanwhile, the amino acid composition showed high glutamate levels $(13.389 \mathrm{~g} / 100 \mathrm{~g})$ as nonessential and histidine $(11.64 \mathrm{~g}$ $/ 100 \mathrm{~g}$ ) as an essential amino acid. The phytochemical composition indicates the presence of bioactive compounds such as; Proanthocyanin $(11,964 \mu \mathrm{g} / \mathrm{g})$, Rutin $(11.8883 \mu \mathrm{g} / \mathrm{g})$, Nanngenin $(3.0122 \mu \mathrm{g} / \mathrm{g})$, Quinine $(10.4490 \mu \mathrm{g} / \mathrm{g})$, Flav-3-ol $(2,5900 \mu \mathrm{g} / \mathrm{g})$, Sparteine $(3,0122 \mu \mathrm{g} / \mathrm{g})$, Phenol (18.8713 $\mu \mathrm{g} / \mathrm{g})$, Flavonones $(2.1836 \mu \mathrm{g} / \mathrm{g})$, Steroids $(18.8974 \mu \mathrm{g} / \mathrm{g})$, Kaempferol $(0.7273 \mu \mathrm{g} / \mathrm{g})$, Phytate $(1,6851 \mu \mathrm{g} / \mathrm{g})$, Naringenin $(2.7523 \mu \mathrm{g} / \mathrm{g})$, Resveratol $(10.8596 \mu \mathrm{g} / \mathrm{g})$, Tannins $(4,4377 \mu \mathrm{g} / \mathrm{g})$ and Ribalinidine (3.0500 $\mu \mathrm{g} /$ g). These bioactive nutrients and phytochemicals in Gotu kola leaves make them useful in the pharmaceutical and food industries [23].

Phytochemical analysis of Gotu kola extract revealed various biochemical compounds such as alkaloids, flavonoids, glycosides, phenolic compounds, triterpenoids, and saponins. Phenolic compounds, triterpenoids, and flavonoids have extraordinary anti-inflammatory, anti-rheumatic and antioxidant activity. Evaluation of the in vitro anti-inflammatory activity, membrane stabilization Human Red Blood Cell (HRBC) was used to inhibit 


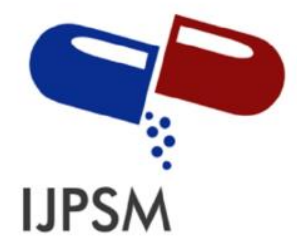

\section{Sesni Yuli Zarmi et al, Int. Journal of Pharmaceutical Sciences and Medicine (IJPSM), Vol.6 Issue. 3, March- 2021, pg. 1-13}

ISSN: 2519-9889

Impact Factor: 3.426

HRBC-induced hypotonicity of membrane lysis. Percentage of Haemolysis was tested with a concentration of $50 \mu \mathrm{g} / \mathrm{mL}$ to $2000 \mu \mathrm{g} / \mathrm{mL}$, and the value decreased from $32.25 \%$ to $5.02 \%$. On the other hand, the percentage of stabilization at the same concentration increased from $67.74 \%$ to $94.97 \%$. Diclofenac sodium was used as a standard drug, and the same experiments were carried out at the same concentration range. And the percentage value of hemolysis was reduced from $47.18 \%$ to $1.24 \%$, and the percentage of stabilization increased from $52.81 \%$ to $98.76 \%$ [12].

Studies to evaluate carotid-femoral plaque echogenicity in asymptomatic subjects with increased oxidative stress and risk factors (mild hypertension, hypercholesterolemia) have been performed. Supplementation with the Pycnogenol-CA (Centella asiatica) combination on plaque echogenicity was assessed at six months (79 subjects). Standard management plans (SM) were used in all subjects (risk factor control, lifestyle changes); 36 subjects used supplement + SM; 43 BC only. The groups are comparable. High-resolution ultrasound evaluates the echogenicity and structure of plaque. Pycnogenol ( $150 \mathrm{mg} /$ day) and CA (Centella asiatica, $450 \mathrm{mg} /$ day) were used for 6 months. Cholesterol levels decreased $(\mathrm{p}<0.05)$ in both groups (the difference between groups was not significant). At 6 months, plasma free radicals were decreased with supplementation $(17.64 \% ; \mathrm{p}<0.05$; vs $<2 \%$ in controls). The plaque stability index increased from $11.22,2.3$ to $22.4,1.1$ ( $\mathrm{p}<0.05$ ) with supplementation; no significant changes were seen in controls. Plaque echogenicity (\% of the "whiter" component in the figure) increased with supplementation from 16.7 to $34.2,2 \%$ ( $\mathrm{p}<0.05$ ); no variation was observed in the controls. The maximum plaque height was decreased $(\mathrm{p}<0.05)$ with supplementation. No significant variations were observed in the controls. Plaque length decreased $(\mathrm{p}<0.05)$ in the supplement group without a change in controls. The amount of plaque (carotid, femoral bifurcations) decreases with supplementation; no significant changes were observed in the controls. No side effects, tolerability problems, or variation in routine blood tests were recorded. The Pycnogenol-CA combination appears to improve the plaque complex's echogenicity and stability at six months [13].

\subsection{Sambiloto (Andrographis paniculata)}

Sambiloto leaves and flowers that can be used to reduce blood lipid levels are shown in Figure 7 below.

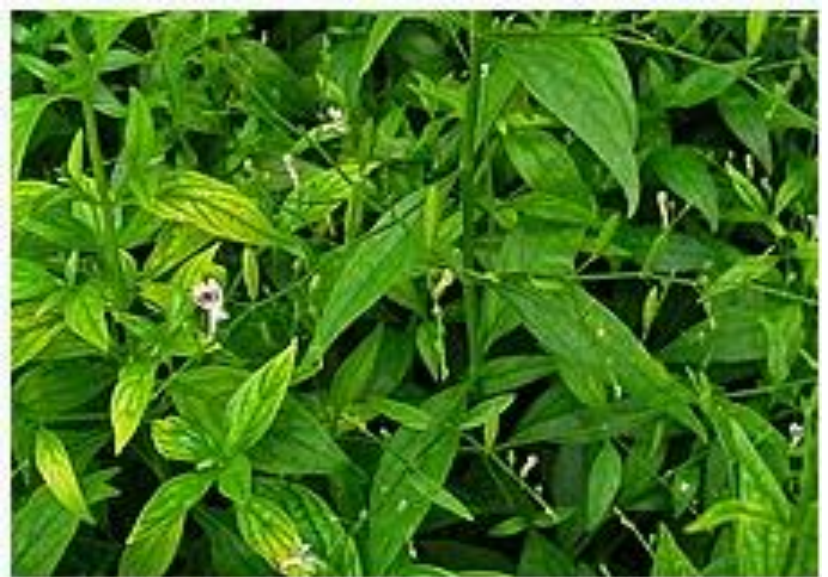

Figure 7: Leaves and flowers of sambiloto (Andrographis paniculata) [14]

The chemical content of sambiloto (Andrographis paniculata) is diterpenoids, flavonoids, and polyphenols [14]. This plant, known as Andrographis paniculata, has many pharmacological properties used to treat several diseases. Leaf, stem, and root extracts prepared in chloroform, methanol, and petroleum ether are used to detect $\beta$-sitosterol from plants. The chromatography process was carried out on TLC plates coated with silica gel 60 $F_{254}$, and the solvent used for the mobile phase was toluene: ethyl acetate: formic acid (15: 4,5: 1,5). After development, the plates were derivatized with $10 \%$ methanol sulfuric acid, scanned, and measured at $510 \mathrm{~nm}$. The results showed the presence of $\beta$-sitosterol in all sections with an $\mathrm{Rf}$ value of 0.62 . The calibration curve was prepared, and the amount of $\beta$-sitosterol was calculated in the extract by comparing each peak area with 


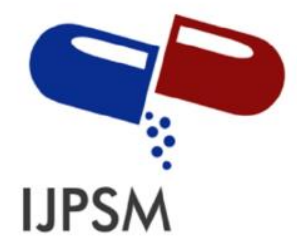

Sesni Yuli Zarmi et al, Int. Journal of Pharmaceutical Sciences and Medicine (IJPSM), Vol.6 Issue. 3, March- 2021, pg. 1-13

ISSN: 2519-9889

Impact Factor: 3.426

the standard. The correlation coefficient for $\beta$-sitosterol against the reference sample was significant $(\mathrm{r}=$ $99.769057 \%$ ) for the concentration range of 0.5 to $4.0 \mu \mathrm{g}$. The methanol extract of the leaves showed the highest $\beta$-sitosterol concentration, namely $147.6 \mu \mathrm{g} / \mathrm{mL}$. The $\beta$-sitosterol extraction efficiency was more elevated in methanol, followed by petroleum ether and chloroform extract. Thus, this study suggests that Andrographis paniculata has a significant concentration of $\beta$-sitosterol, which may be useful for pharmacological applications against cancer, hypercholesterolemia, inflammation, and angiogenesis processes [15].

Cholesterol is one of the causes of coronary heart disease. In the experimental method using a completely randomized design (CRD) 3 replications, 6 treatments, namely: 1) D0 = normal control; 2) D1 = positive cholesterol control; 3) D2 = comparator simvastatin $2 \mathrm{mg} / 200 \mathrm{~g}$ body weight; 4) D3 = dose of sambiloto 100 $\mathrm{mg} / 200 \mathrm{~g}$ body weight; 5) D4 = dose $200 \mathrm{mg}$ of sambiloto / $200 \mathrm{~g}$ of body weight; 6) D5 = dose of $400 \mathrm{mg}$ of sambiloto / $200 \mathrm{~g}$ of body weight. The mice that have been tested are white male Wistar rats aged two months weighing $\pm 200 \mathrm{~g}$. Analysis using ANOVA, and further test using DMRT, $\alpha 5 \%$. The results showed that the extract of sambiloto $100 \mathrm{mg} / 200 \mathrm{~g}$ body weight, $200 \mathrm{mg} / 200 \mathrm{~g}$ body weight, $400 \mathrm{mg} / 200 \mathrm{~g}$ body weight, and the comparison of simvastatin $2 \mathrm{mg} / 200 \mathrm{~g}$ body weight could all reduce the total blood cholesterol levels of rats made to become hypercholesterolemic. Interestingly, a dose of $400 \mathrm{mg} / 200 \mathrm{~g} \mathrm{BW}$ had the same ability as simvastatin at a dose of $2 \mathrm{mg} / 200 \mathrm{~g} \mathrm{BW}$ in reducing the total blood cholesterol levels of rats by $51 \%$, considering the risk of hypocholesterolemia [16].

\subsection{Sweet Potato (Ipomoea batatas L.)}

Sweet potato leaves and flowers that can reduce blood lipid levels are shown in Figure 8 below.

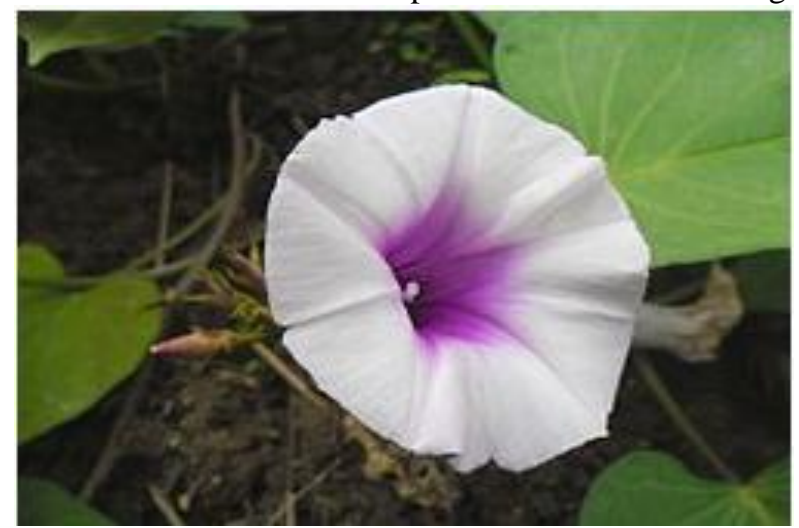

Figure 8: Sweet potato (Ipomoea batatas L.) leaves and flowers [17]

Sweet potato leaves are plant leaves containing chemicals such as polyphenols, flavonoids, quercetin, tannins, and fiber, which effectively reduce total cholesterol levels. Increased total cholesterol levels increase the risk of cardiovascular disease. To analyze the effect of ethanol extract of purple sweet potato leaves on serum total cholesterol levels, rats fed a high-fat diet. An experimental study with pre and post-test design was conducted on ten male Wistar rats (Rattus norvegicus) fed a high-fat diet, namely two groups: 1 hyper cholesterol control group and 1 group of ethanol extract of purple sweet potato leaves. The dosage is based on the quercetin leaf content, which is $2 \mathrm{mg} / \mathrm{kg} \mathrm{BW}$. The average ethanol content of quercetin purple sweet potato leaf extract was obtained at $14.08 \mathrm{mg} / 100 \mathrm{~g}$. The ethanol extract of purple sweet potato leaves was given for 14 days using a sonde. Serum total cholesterol was determined by the CHOD-PAP method. The data obtained were analyzed descriptively. The results showed that the average total cholesterol level of white blood rats before giving ethanol extract of purple sweet potato leaves was $189.89 \mathrm{mg} / \mathrm{dL}$. After giving ethanol extract of purple sweet potato leaves, a $2 \mathrm{mg} / \mathrm{kg}$ bb was $131.92 \mathrm{mg} / \mathrm{dL}$. The decrease in white rats' total cholesterol level after giving ethanol extract of purple sweet potato leaves at a dose of $2 \mathrm{mg} / \mathrm{kg}$ body weight was $30.52 \%$ [18]. 


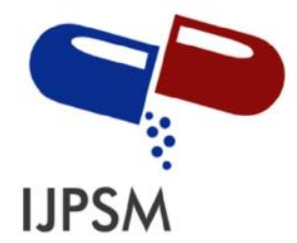

Sesni Yuli Zarmi et al, Int. Journal of Pharmaceutical Sciences and Medicine (IJPSM), Vol.6 Issue. 3, March- 2021, pg. 1-13

ISSN: 2519-9889

Impact Factor: 3.426

\subsection{Sambung Nyawa or "life extension" (Gynura procumbens)}

The "life extension" leaves that can be used to lower blood fat levels are shown in Figure 9 below.

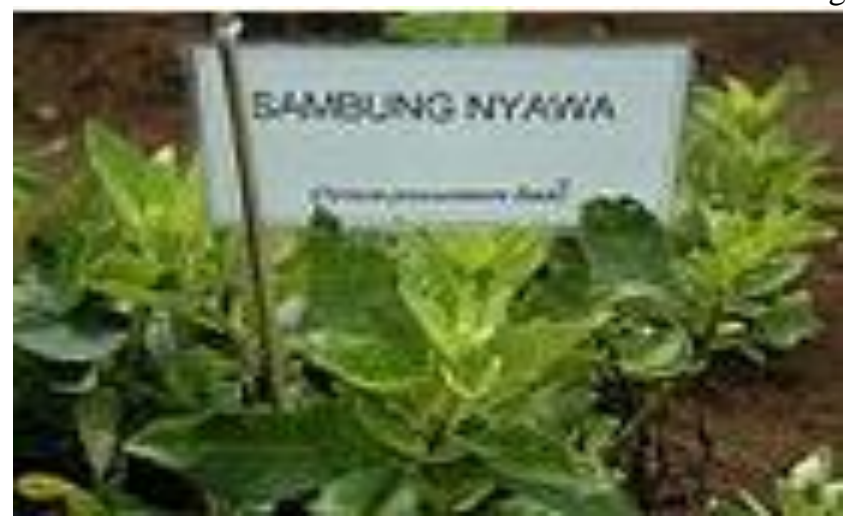

Figure 9: Sambung Nyawa or “life extension' (Gynura procumbens) [19]

The leaves of Sambung Nyawa are non-toxic and exhibit antidiabetic, anti-inflammatory, antihypertensive, and wound healing properties. This plant extract contains active chemicals such as tannins, terpenoids, sterol glycosides, saponins, and flavonoids. Antioxidants work against oxidants and free radicals by donating their scoped electrons to radical molecules and neutralizing oxidation processes in biological systems [20].

Gynura procumbens has antihyperlipidemic, antioxidant, and cardioprotective properties. To determine the effect of $80 \%$ ethanol extract of Gynura procumbens on the lipid profile and oxidative status of hypercholesterolemic rats, postmenopausal (PM) Sprague-Dawley rats were ovariectomized and fed $2 \%$ cholesterol fortified with palm oil to develop hyperlipidemia status. Two doses of the extract (250 and 500 $\mathrm{mg} / \mathrm{kg}$ ) and atorvastatin $(10 \mathrm{mg} / \mathrm{kg}$ ) were given once daily by oral gavage for 24 weeks. Systolic blood pressure (SBP) increased during the first month in the postmenopausal group and decreased with Gynura procumbens supplementation. Lipid droplet accumulation was seen in the tunica media (TM) area of the aorta in the postmenopausal group and was reduced by Gynura procumbens supplementation. Total cholesterol (TC), total triglycerides (TG), low-density lipoprotein (LDL), and malondialdehyde (MDA) increased ( $\mathrm{p}<0.05$ ) at 3 and 6 months in the postmenopausal group and were reduced by Gynura procumbens supplementation. Gynura procumbens also increased high-density lipoprotein (HDL) levels in the postmenopausal group. Superoxide dismutase (SOD), catalase (CAT), and glutathione peroxidase (GPx) activity were reduced in the postmenopausal group compared to controls but increased $(\mathrm{p}<0.05)$ with Gynura procumbens supplementation. It suggests that a higher dose of Gynura procumbens $(500 \mathrm{mg} / \mathrm{kg})$ gives a better effect. Gynura procumbens can reduce oxidative stress and prevent cell membrane damage by modifying antioxidant enzyme activity and changes in lipid profiles in postmenopausal mice associated with atherosclerosis [21].

\section{Conclusion}

Indonesian plants that have anti-hypercholesterolemic properties are Salam (Syzygium polyanthum), AlangAlang (Imperata cylindrica L), Pegagan (Centella asiatica L.), Sambiloto (Andrographis paniculata), Sweet Potatoes (Ipomoea batatas), and Sambung Nyawa (Gynura procumbens). These plants contain various phytochemical compounds which are efficacious in reducing fat blood levels. Therefore, these six plants have the potential to be developed into phytopharmaca as anti-hypercholesterolemic herbal medicine. 


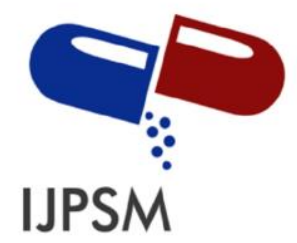

Sesni Yuli Zarmi et al, Int. Journal of Pharmaceutical Sciences and Medicine (IJPSM), Vol.6 Issue. 3, March- 2021, pg. 1-13

ISSN: 2519-9889

Impact Factor: 3.426

\section{References}

[1]. Badan Pengawas Obat dan Makanan Republik Indonesia. Formularium Ramuan Obat Tradisional Indonesia. Ramuan Etnomedisin. (Vol 1). Jakarta: Badan Pengawas Obat dan Makanan Republik Indonesia, 2011.

[2]. https://en.wikipedia.org/wiki/Hypercholesterolemia

[3]. https://id.m.wikipedia.org/wiki/Salam_(tumbuhan)

[4]. Kusuma IW, Kuspradini H, Arung ET, Aryani F, Min YH, Kim JS, Kim YU. Biological activity and phytochemical analysis of three Indonesian medicinal plants, Murraya koenigii, Syzygium polyanthum and Zingiber purpurea. Journal of Acupuncture and Meridian Studies. 2011 Mar 1;4(1):75-9.

[5]. Abd Rahim EN, Ismail A, Omar MN, Rahmat UN, Ahmad WA. GC-MS analysis of phytochemical compounds in Syzygium polyanthum leaves extracted using ultrasound-assisted method. Pharmacognosy Journal. 2018;10(1):110-9. http://dx.doi.org/10.5530/pj.2018.1.20

[6]. Wirawan W, Adrianus C, Anam S. efek ekstrak etanol kombinasi Daun Ceremai dan Daun Salam terhadap penurunan kolesterol total tikus. Farmakologika: Jurnal Farmasi. 2018;15(1):46-53.

[7]. Wijaya S, Darsono FL. The Lipid-Lowering Effect of Water Extract of Andrographis paniculata, Water Extract of Syzygium polyanthum and its Combination in Alloxan-Induced Diabetic Rats. PROCEEDING, The Application of Herbal Medicine Jamu and other Complementary Alternative Medicine in Indonesian Integrative Medicine Surabaya, 1st International Symposium of Traditional Complementary and Alternative Medicine Shangri-La, 1th-13th April 2014

[8]. https://id.m.wikipedia.org/wiki/Alang-alang

[9]. Khaerunnisa S, Aminah NS, Kristanti AN, Kuswarini S, Wungu CD, Soetjipto S, Suhartati S. Isolation and identification of a flavonoid compound and in vivo lipid-lowering properties of Imperata cylindrica. Biomedical Reports. 2020 Nov 1;13(5):1-8. http://dx.doi.org/10.3892/br.2020.1345

[10]. Anggraeni N, Syamsunarno MR, Mukarromah GR, Zada A, Triatin RD, Pamela Y, Dhianawaty D. Low Serum Cholesterol Mice Pre-treated with Imperata cylindrica L. after Acute Olive Oil Gavage. KnE Life Sciences. 2017 Dec 3:460-7. http://dx.doi.org/10.18502/kls.v3i6.1155

[11].https://id.m.wikipedia.org/wiki/Pegagan

[12]. Baby MS, Antony AV, John B, Jose D. Phytochemical Screening And Invitro Anti-Inflammatory ActivityOf Ethanolic Extract of Centella asiatica. World Journal of Current Medical and Pharmaceutical Research. 2020 May 4:181-3.

[13]. Belcaro G, Cornelli U. Variations in echogenicity in carotid and femoral atherosclerotic plaques with Pycnogenol + Centella asiatica supplementation. The International Journal of angiology: official publication of the International College of Angiology, Inc. 2017 Jun;26(2):95-101. http://dx.doi.org/10.1055/s-0036-1594292

[14].https://id.m.wikipedia.org/wiki/Sambiloto

[15]. Yusron, M. Dan M. Januwati. Effect of Argoecological Conditions on the Production and Quality of Simplisia Sambiloto (Andrographis paniculata Ness.) Proceedings. National Conference on Indonesian Medicinal Plants. XXVI. Pokjarnas Indonesian Medicinal Plants. 211- 231. 2004.

[16].Lahare RP, Kumar A. HPTLC Based Screening of $\beta$-Sitosterol from Andrographis paniculata. Nature Environment and Pollution Technology. 2019 Sep 1;18(3):949-54.

[17].Sudarmi, M., Darmini, W., \& Wartini, M. Activity of Sambiloto Extract (Andrographis paniculata Ness) in Reducing Total Blood Cholesterol Levels Hypercholesterolemia Rats. In International Conference on Applied Science and Engineering (ICASE 2018) 2018, Oct. (pp. 120-122). Atlantis Press.

[18].https://id.m.wikipedia.org/wiki/Ubi_jalar

[19].Fatimah S, Arisandi D, Saputri MS. Total Cholesterol Level of Hypercholesterolemia Male Wistar Rats (Rattus norvegicus) with Ethanol Extracts of Purple Sweet Potato Leaf (Ipomoea batatas (L.) Lam). Journal of Health (JoH). 2018 Jan 31;5(1):33-9. 


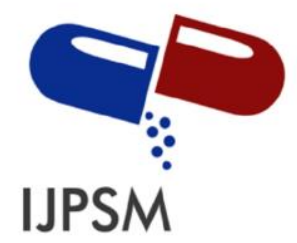

Sesni Yuli Zarmi et al, Int. Journal of Pharmaceutical Sciences and Medicine (IJPSM), Vol.6 Issue. 3, March- 2021, pg. 1-13

ISSN: 2519-9889

Impact Factor: 3.426

[20].https://id.m.wikipedia.org/wiki/Sambung nyawa

[21].Ismail MA, Bahari EA, Ibrahim FS, Dasiman R, Amom Z. Effects of Gynura procumbens extract on liver function test of hypercholesterolemia induced rabbits. Jurnal Teknologi. 2016 Jun 15;78(6-7).

[22]. Ahmad Nazri KA, Fauzi NM, Buang F, Mohd Saad QH, Husain K, Jantan I, Jubri Z. Gynura procumbens standardized extract reduces cholesterol levels and modulates oxidative status in postmenopausal rats fed with cholesterol diet enriched with repeatedly heated palm oil. EvidenceBased Complementary and Alternative Medicine. 2019 Sep 23;2019.(1-16). https://doi.org/10.1155/2019/7246756

[23]. Ogunka-Nnoka CU, Igwe FU, Agwu J, Peter OJ, Wolugbom PH. Nutrient and Phytochemical Composition of Centella asiatica Leaves. Med Aromat Plants (Los Angeles). 2020;9(346):2167-0412. DOI: $10.35248 / 2167-0412.20 .9 .346$

\section{A Brief Author Biography}

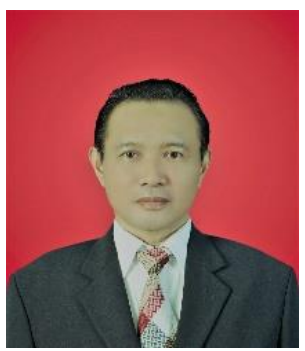

Prof. Dr. Harrizul Rivai, M.S., was born in Payakumbuh, West Sumatra, on 4 September 1953. His father is Rivai Said, and his mother is Saridahanum Syofyan. The Author obtained a Bachelor of Pharmacy from the Department of Pharmacy, Faculty of Mathematics and Natural Sciences, Padjajaran University, Bandung (1976), a Master of Science degree from the Bandung Institute of Technology (1984), and a Doctorate from the Department of Chemistry, Faculty of Mathematics and Natural Sciences, Andalas University, Padang (2011). Now the Author is a Professor and Researcher at the Faculty of Pharmacy, Andalas University, Padang. The Author also serves as Deputy Chair of Academic Affairs at the YPTIK Padang College of Pharmacy (STIFARM). The Author wrote the book "Principles of Chemical Examination" (Publisher UIPress, 1995), translated the book "Pharmaceutical Statistics" (EGC Medical Book Publishers, 2010), and wrote "Chapter 4" in the book "Recent Research Advances in Biology Vol. 4 "(International Book Publisher, India, and United Kingdom, 2020). The Author has also written articles in various international journals in various science fields, such as chemistry, biology, and pharmacy. 